\title{
HISTOPATHOLOGY OF HEPATIC SINUSOIDAL OBSTRUCTION SYNDROME AFTER NEOADJUVANT OXALIPLATIN-BASED CHEMOTHERAPY
}

Marjan Micev ${ }^{1}$, Dragan Basaric ${ }^{2}$, Milena Cosic Micev ${ }^{1}$ and Danijel Galun ${ }^{2}$

${ }^{1}$ Department of Histopathology, Clinical Centre of Serbia, Belgrade, Serbia

${ }^{2}$ Clinic of Digestive Surgery - First Surgical Clinic, Clinical Centre of Serbia, Belgrade, Serbia

\author{
HISTOPATOLO GIJA SINDROMA SINUSOIDALNE OPSTRUKCIJE JETRE \\ NAKON NEOADJUVANTNE HEMOTERAPIJE NA BAZI \\ OKSALIPLATINA \\ Marjan Micev ${ }^{1}$, Dragan Basarić ${ }^{2}$ Milena Ćosić Micev ${ }^{1}$ i Danijel Galun² \\ ${ }^{1}$ Služba za patohistologiju, Klinički centar Srbije, Beograd, Srbija \\ ${ }^{2}$ Klinika za digestivnu hirurgiju - Prva hirurška klinika, Klinički centar Srbije, Beograd, Srbija
}

Received / Primljen: 27. 03. 2017.

Accepted / Prihvaćen: 21. 05. 2017.

\begin{abstract}
Sinusoidal obstruction syndrome („blue liver syndrome“) has been frequently associated with oxaliplatin-based neoadjuvant chemotherapy in patients with colorectal liver metastasis. Hepatotoxic vascular lesions in the nontumourous liver parenchyma result in hypoperfusion and tissue hypoxia leading to lower tumour response to oncologic treatment and to increase the risk of liver metastasectomies. Furthermore, hepatic parenchyma injuries could be aggravated by hepatic resection itself. Contrary to standard surgical techniques, radiofrequency assisted liver resection significantly reduce harmful intraoperative blood loss and perfusion-reperfusion effects. We compared histological alterations in 59 specimens of bloodless radiofrequency-assisted liver recetions made for colorectal metastases to those in 38 specimens of standard liver resections. In general, the main histologic alterations in both examined groups related to oxaliplatin include SOS lesions (69.35\%), fibrosis (50.95\%) and steatosis (38\%). After scoring of histopathological parameters based on modified criteria according to Rubbia-Brandt et al., they were statistically insignificant between both groups for portal and/ or porto-portal fibrosis (59.3\% vs 47.4\%, respectively) and moderate/severe macrovacuolar steatosis (10.2\% vs 26.3\%). Similar distribution between groups was shown for surgical hepatitis with "borderline" statistical significance (23,7\% vs $42,1 \%, p=0.05)$. However, there were significant differencies in vascular lesions, particularly for hemorrhagic centrilobular necrosis $(10,2 \%$ vs $31,5 \%, p=0.01)$ and peliosis $(15,2 \%$ vs $36,8 \%, p=0.04)$, but were not significant for sinusoidal dilatation and congestion as well as surgical necrosis. Highgrade vascular lesions such as hemorrhagic centrilobular necrosis and peliosis are less frequent in cases of radiofrequency-assisted liver recetions and might be associated with better clinical outcome in these patients.
\end{abstract}

Keywords: sinusoidal obstruction syndrome, hepatic vascular lesions, oxaliplatin, hepatotoxicity, colorectal liver metastases, liver resection

\section{SAŽETAK}

Sindrom sinusoidalne opstrukcije ("sindrom plave jetre") je često povezan s primenom neoadjuvantne hemoterapije na bazi oksaliplatina kod pacijenata sa kolorektalnim metastazama u jetri. Hepatotoksične vaskularne lezije u netumorskom parenhimu jetre rezultiraju hipoperfuzijom $i$ hipoksijom tkiva i slabijim odgovorom tumora na onkološki tretman i povećavanjem rizika za resekcije jetrenih metastaza. Osim toga, povrede jetrenog parenhima mogu biti otežane samom hepatalnom resekcijom. Za razliku od standardnih resekcija jetre, radiofrekventne hirurške tehnike mogu značajno smanjiti štetne efekte intraoperativnog gubitka krvi i fenomena perfuzije-reperfuzije. Uporedili smo histološke promene u 59 slučajeva beskrvne radiofrekventne resekcije jetre učinjenih zbog kolorektalnih metastaza s onima u 38 slučajeva standardnih resekcije jetre. Generalno, glavne histološke promene jetre nakon upotrebe oksaliplatina u obe ispitivane grupe se odnose na SOS lezije (69.35\%), fibrozu (50.95\%) i steatozu (38\%). Nakon bodovanja histopatoloških parametara na osnovu modifikovanih kriterijuma Rubia-Brandt $i$ saradnika, nije bilo statistički značajne razlike između obe grupe za portnu i/ ili porto-portnu fibrozu (59,3\% prema 47,4\%) i za umerenu/ tešku makrovakuolarnu steatozu (10.2\% u odnosu na 26,3\%). Slična distribucija izmedu ispitivanih grupa je pokazana za hirurški hepatitis sa "graničnim" statističkim značajem (23,7\% prema 42,1\%, p =0,05). Međutim, utvrđena je značajna razlika za vaskularne lezije, naročito za hemoragijsku centrilobularnu nekrozu (10,2\% prema 31,5\%, p = 0.01) i peliozu $(15,2 \%$ u odnosu na 36,8\%, p =0,04), ali nije bilo statistički značajne razlike za sinusoidalnu dilataciju $i$ kongestiju kao $i$ za hiruršku nekrozu. Visoko rizične vaskularne lezije, kao što su hemoragijska centrilobularna nekroza i pelioza ređe su u slučajevima radiofrekventne resekcije jetre i mogu biti povezane sa boljim kliničkim ishodom kod ovih bolesnika.

Ključne reči: sindrom sinusoidalne opstrukcije, vaskularne lezije jetre, oksaliplatin, hepatotoksičnost, kolorekralna jetrena metastaza, resekcija jetre
Corresponding author: Marjan Micev, M.D., Ph.D. Marjan Micev, M.D., Ph.D.
Clinical Centre of Serbia, Department of Histopathology,
Koste Todorovica 6, 11000 Belgrade, Serbia E-mail micevm@gmail.com Tel: +381 113610646 Fax: +381113615655 


\section{ABBREVIATIONS}

RALR - radiofrequency-assisted liver resection

CASH - chemotherapy associated steatohepatitis

SOS - sinusoidal obstruction syndrome

\section{INTRODUCTION}

Sinusoidal obstruction syndrome (SOS) is distinctive hepatotoxic and rapidly developing vascular lesion with compromised hepatic microcirculation. SOS has a strong potential to lethal liver failure and portal hypertension-related complications (1). It is also known as "blue liver syndrome" because of its characteristic intraoperative subcapsular livid appearance and similar macroscopic "marble“ bluish-red discoloration on cut surface. SOS is caused by toxic injury to hepatic sinusoidal endothelial cells producing their swelling and leading to the loss of sinusoidal wall integrity, impaired sinusoidal blood flow and consequent sinusoidal congestive obstruction (2). In some cases it can result in further obstructive fibrovascular alterations on hepatic veins and is often associated with other histopathologic findings in the liver parenchyma. Therefore, this syndrome was originally described as hepatic venoocclusive disease, but since DeLeve et al. coined the term SOS, previous term is no longer recommended primarily because the major lesion is located at the level of hepatic sinusoids, not necessarily involving centrilobular vein (3). The classical clinical triad of SOS includes ascites, hepatomegaly and increased bilirubin levels $(>2 \mathrm{mg} / \mathrm{dl}$ ), but one can often find other signs of portal hypertension, weight gain, pleural effusion, lower limbs edema, splenomegaly and rarely upper gastrointestinal bleeding. The frequent recognition of SOS has resulted from numerous complications after the use of chemotherapy before hemopoietic stem cell transplantation, immunosuppressive agents in solid organ transplantation and inflammatory bowel diseases, after irradiation as well as long list of hepatotoxic drugs and herbal remedies, including frequent oncologic treatment of colorectal liver metastases by oxaliplatin (4). Contrary to the West, in the Far East SOS is usually caused by herbal medicine containing pyrrolizidine alkaloids (5).

The liver is most common site of colorectal carcinoma metastases with initial rate of metastatic disease estimated to $15-20 \%$ of all patients (6). Oxaliplatin is frequently used as a part of neoadjuvant or systemic chemotherapy prior to hepatic resection of colorectal cancer liver metastases in patients who were estimated as initially inoperable (7). The results of combined medical oncology and modern surgery increase the number of curative liver resections from 15\% to $30 \%$ and 5 -year survival rates are reported to be $30-35 \%$ $(8,9)$. However, oxaliplatin-based chemotherapy provokes sinusoidal obstruction syndrome in association with other histologic alterations of liver tissue not involved by tumor
(10). Hepatic steatosis was initially regarded as the most significant pathological alteration in these settings and all other changes, including vascular changes, were attributed to steatohepatitis or secondary effects (11). At present, more scientific reports favour vascular lesions to be more closely associated with prehepatectomy oxaliplatincontaining regimens over steatosis and chemotherapy associated steatohepatitis (CASH) in the non-tumour liver parenchyma. As a consequence, SOS after neoadjuvant oxaliplatin-based chemotherapy might significantly increase morbidity, reduces the effect of oxaliplatin, bevacizumab or other chemotherapeutic agents in colorectal metastases (lower tumour response to oncologic treatment) and increases the risk of liver resection metastasectomies.

Liver resection itself can contribute further histologic changes since intraoperative blood loss and perfusionreperfusion effects are often associated with postoperative morbidity, mortality and shorter long-term survival. The introduction of advanced surgical techniques have increased the percentage of curative liver resections, such as the novel technique of radiofrequency-assisted liver resection (RALR), which is thought to be transfusion-free, easy and safe (12). It broadens therapeutic options for patients with initially unresectable colorectal liver metastases and convert them to resectability.

The aim of this study was to assess the frequency and severity of SOS and associated histologic alterations in the non-tumor bearing liver parenchyma in the resected specimens after oxaliplatin-based chemotherapy in patients with colorectal liver metastases. However, little is known about possible differences between liver resection-related histologic alterations in standard resections and RALR. Therefore, SOS and its histologic variables and other hepatic alterations were correlated to main liver resection types.

\section{MATERIAL AND METHODS}

In a retrospective study a total of 97 liver resection specimens were examined from patients with colorectal liver metastases from November 2001 to December 2005 in a single institution (First Surgical Clinic, Clinical Centre of Serbia, Belgrade) who had been previously operated for colorectal cancer, underwent preoperative neoadjuvant oxaliplatin-based chemotherapy and first partial hepatec- 
Table 1. Indications for radiofrequency-assisted liver resection (RALR) with minimal blood loss and facilitated tissue sparing, potentially reducing the risk of the development of SOS

\begin{tabular}{lcc}
\hline Indications for resection & Patients & n \% \\
\hline Colorectal metastases & 59 & 65.7 \\
Primary liver cancer & 17 & 18.9 \\
Giant liver hemangioma & 3 & 3.3 \\
Lung cancer metastases & 2 & 2.2 \\
Ovary cancer metastases & 1 & 1.1 \\
Gallbladder cancer & 1 & 1.1 \\
Liver hydatid cyst & 2 & 2.2 \\
Liver cystadenoma & 1 & 1.1 \\
Recurrent liver abscess & 1 & 1.1 \\
Liver actinomycosis & 1 & 1.1 \\
Solitary necrotic liver nodule & 1 & 1.1 \\
Metastasis - undetectable primary tumor & 1 & 1.1 \\
Total & $\mathbf{9 0}$ & $\mathbf{1 0 0 . 0}$ \\
\hline
\end{tabular}

tomy. The majority of patients (59/90) were among cases with strong indications for RALR as a new surgical technique in a series of 81 patients with malignant tumors and 9 patients with benign diseases (Table 1). The rest of 38 patients were underwent standard surgical procedures for metastasectomies which all needed blood transfusion after significant blood loss (>1 unit of packed red blood cells transfusion). Selection of cases followed this exclusion criteria: (a) less than 6 cycles regimen of preoperatively chemotherapeutic treatment with fluorouracil plus oxaliplatin; (b) extrahepatic spread of the disease; (c) no sufficient amount of remnant non-tumour bearing liver parenchyma; (d) other known vascular disorders or focal lesions, including hemangioma; (e) simultaneous operative procedures on other organs and (f) less than 6 months period of successful postoperative follow-up.

Selected tissue samples were taken from non-tumour bearing liver parenchyma at minimum distance of $20 \mathrm{~mm}$ from the tumour, avoiding subcapsular region and from peritumoural zone. Standard $4 \%$ buffered formalin fixed and paraffin embedded samples were cut and 4- $\mu \mathrm{m}$ sections routinely stained for hematoxylin-eosin, reticulin and Masson trichrome staining. Histomorphological analysis and scoring of histopathological parameters were based on the criteria according to Rubbia-Brandt et al. (table 2) (13). In concordance with the study of Aloia et al. we focused mainly to categories of vascular lesions, fibrosis and macrovesicular steatosis (14). In addition to these morphological variables, we examined the presence of necrotic lesions induced by operative manipulation of the liver, so-called surgical hepatitis (surgical necrosis) defined by hepatocyte

Table 2. Histological features of hepatic sinusoidal obstructive syndrome (SOS) evaluated according to Rubbia-Brandt L. et al. (13)

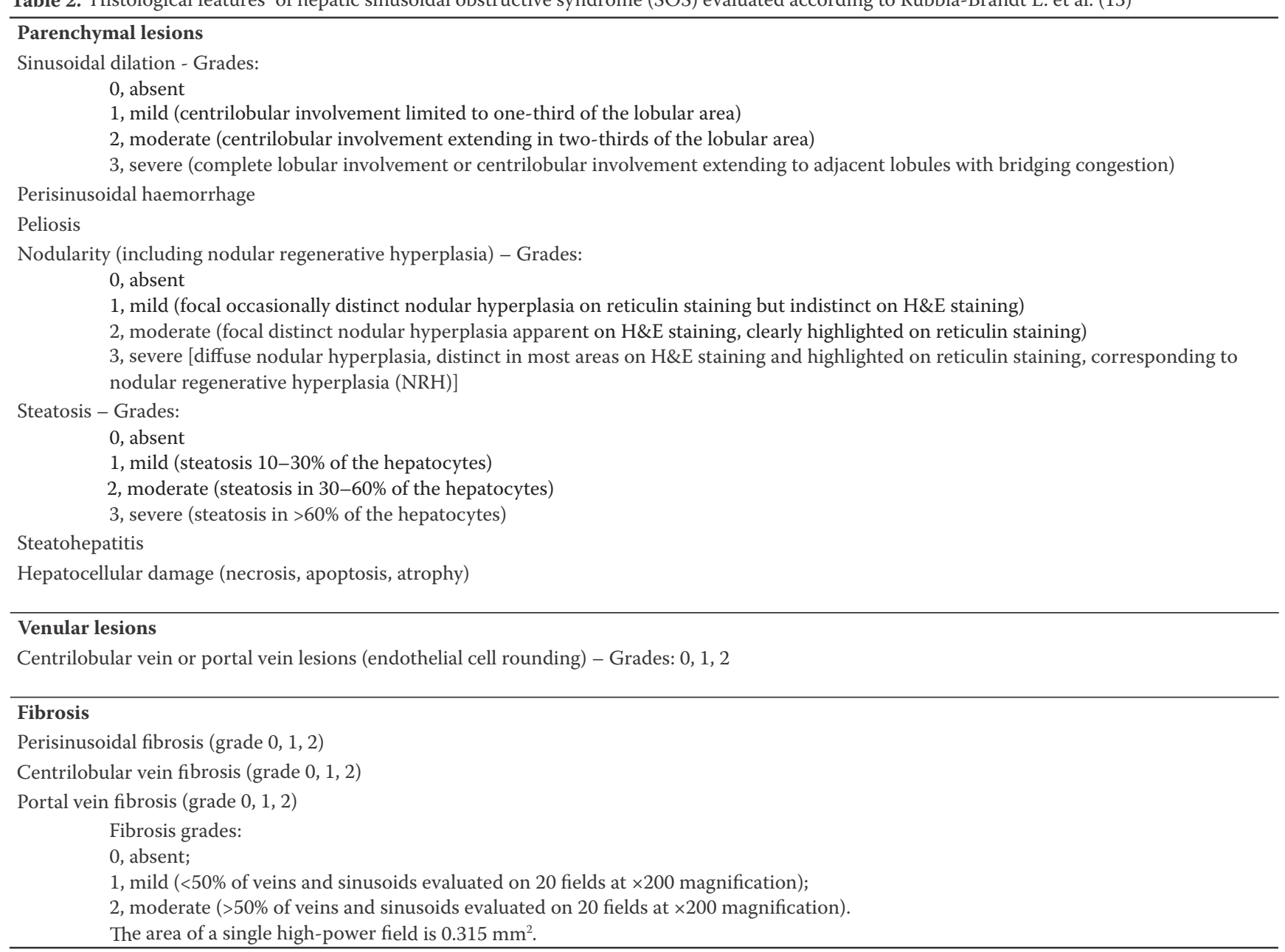




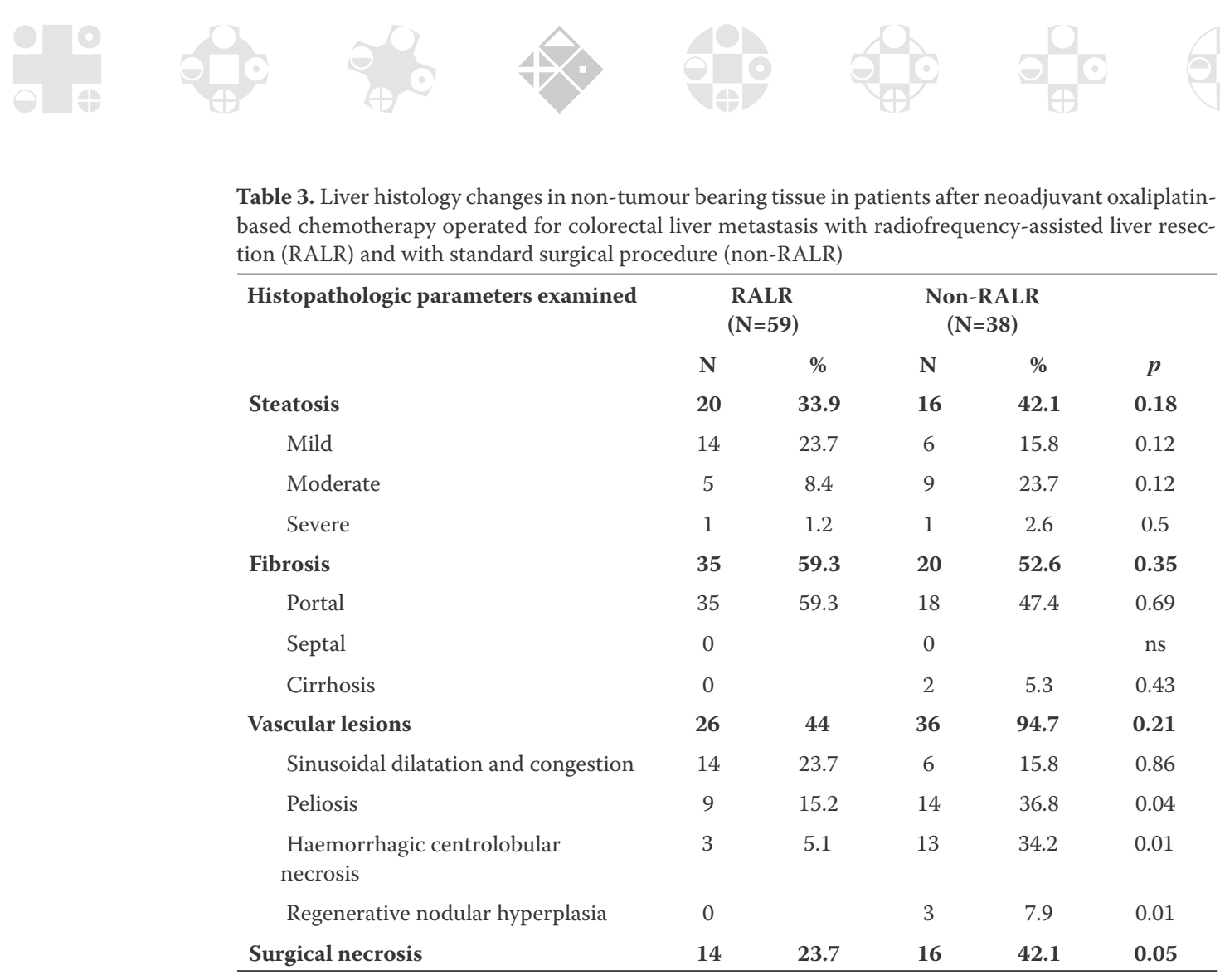

necrosis associated with neutrophils that is disseminated throughout the periportal or centrilobular areas.

Detailed histological examination of 59 specimens was performed on samples of liver specimens of transfusionfree RALR and was compared to histological changes on samples of non-tumorous liver tissue from 38 specimens of standard liver resections. Furthermore, we analyzed samples distal and proximal to the treated tumour, i.e. samples taken from non-tumour bearing liver parenchyma at minimum distance of $20 \mathrm{~mm}$ from the tumour and compared to those from peritumoural zone.

Statistical analysis were performed using SPSS version 15.0 statistical software (SPSS Inc., Chicago, IL, USA). The chi-square test was used to correlate the different groups of patients according to the liver resection types versus the presence of lesions associated with oxaliplatin based chemotherapy. $P$-values were considered statistically significant if $<0.05$.

\section{RESULTS}

The study included 97 patients previously operated for colorectal cancer and underwent preoperative neoadjuvant oxaliplatin-based chemotherapy for colorectal liver metastases. There were 50 men and 47 women, ranging from 18 to 78 years old (mean age 57.71 years). According to subsequent liver resection type they were divided in two groups: 59 patients underwent bloodless radiofrequencyassisted liver resection (RALR), and 38 patients were treated by standard surgical procedures for colorectal metastasectomies (non-RALR).
Detailed histomorphological examination on oxaliplatin-related histological alterations comprises 59 specimens of non-tumorous liver tissue (RALR group) and 38 specimens of cases with standard liver resections (non-RALR group) including both samples taken from non-tumour bearing liver parenchyma at minimum distance of $20 \mathrm{~mm}$ from the tumour and those from peritumoural zone. After careful examination and scoring of numerous histomorphological parameters we systematized them in ascending order of severity, mostly grouping them to low-grade and high-grade lesions. SOS lesions were divided according to grading systems in two groups: low-grade lesions included grades 0 (absent) and 1 (mild) and high-grade lesions included grades 2 (moderate) and 3 (severe). For histological analysis of SOS parameters in this study we finally reported only high-grade lesions (moderate or severe grades).

We found most frequent and most important four histologic entities: (a) fibrosis, futher categorized as portal fibrosis, porto-portal fibrosis, septal fibrosis, and cirrhosis; (b) vascular lesions, specified as sinusoidal vasodilatation and congestion, peliosis, hemorrhagic centrilobular necrosis and regenerative nodular hyperplasia; (c) macrovacuolar steatosis, and (d) surgical hepatitis (surgical necrosis). The most important histopathological alterations in both examined groups are briefly presented (Table 3 ).

In general, the main histologic alterations in both examined groups related to oxaliplatin include SOS lesions (69.35\%), fibrosis (50.95\%) and steatosis (38\%). After scoring of histopathological parameters based on modified criteria according to Rubbia-Brandt et al., they were statistically insignificant between both groups for portal and/or porto-portal fibrosis ( $59.3 \%$ vs $47.4 \%$, respectively) 

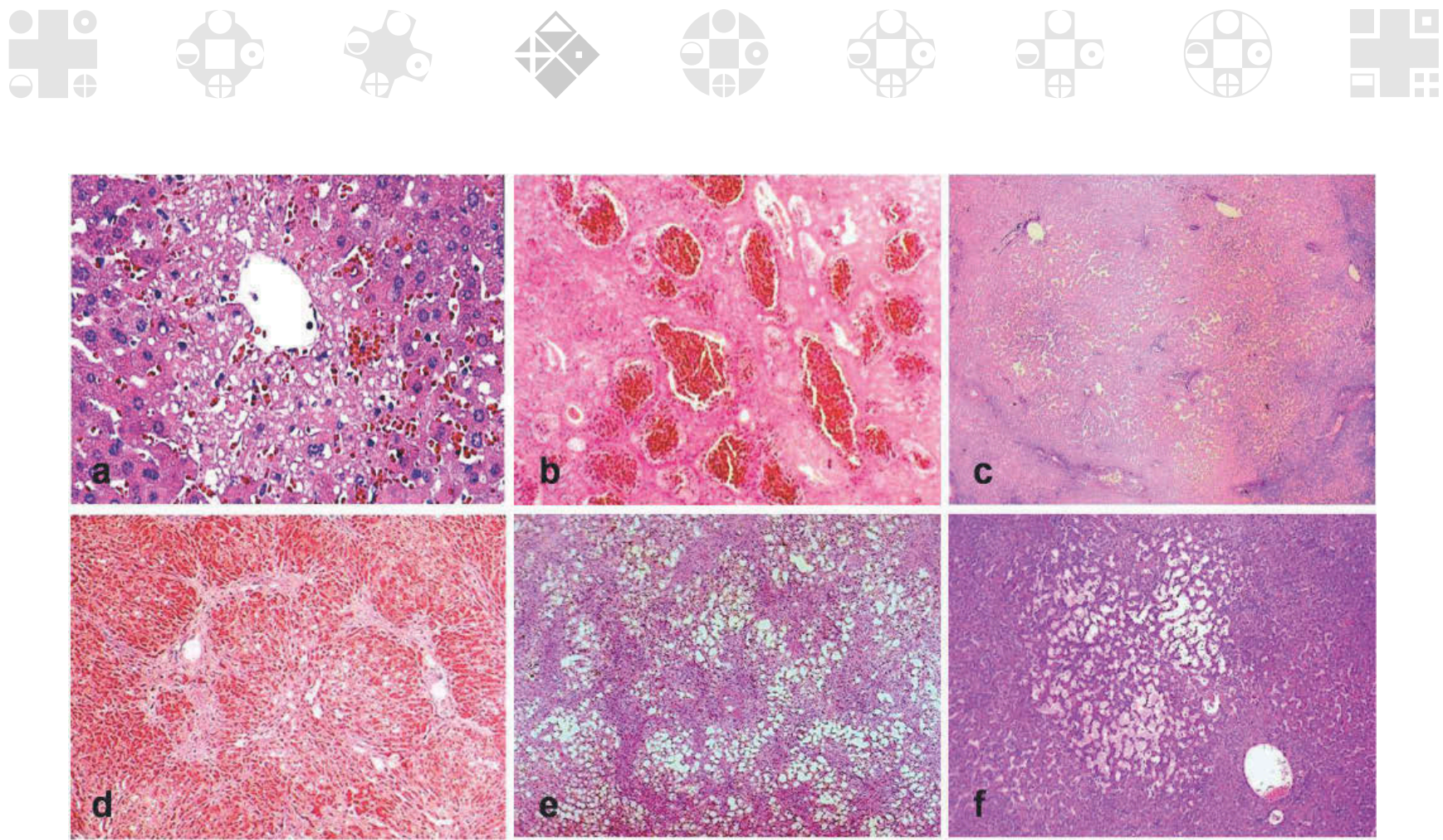

Figure 1. High-grade SOS lesions were seen more often in non-RALR group of patients and may be related to worse clinical outcome in this group of patients such as: hemorrgahic centrilobular necrosis (a) and peliosis, representing large haemorrhagic cystic-like pattern of sinusoidal dilation, (b) as well as regenerative nodular hyperplasia (c). The most consistent findings in non-tumoural liver tissue related to effects of neoadjuvant oxaliplatin-based chemotherapy were: portal fibrosis (d), macrovacuolar steatosis (e) and sinusoidal dilatation (f)

and moderate/severe macrovacuolar steatosis $(10.2 \%$ vs 26.3\%), some of the with elements of CASH. We have not seen isolated centrilobular vein thrombosis and fibrosis which is quite interesting and unusual result. Similar distribution between groups was shown for surgical hepatitis with „borderline“ statistical significance (23.7\% vs $42.1 \%$, $p=0.05)$. However, there were significant differencies in "high-grade" SOS vascular abnormalities, particularly in the presence of hemorrhagic centrilobular necrosis $(10.2 \%$ vs $31.5 \%, p=0.01)$ and peliosis $(15.2 \%$ vs $36.8 \%, p=0.04)$, but were not significant in the presence of sinusoidal dilataton and congestion as well as surgical necrosis. Two cases of micronodular cirrhosis were noted only in RALR group and three cases of regenerative nodular hyperplasia and two cases of hepatic atrophy only in non-RALR group. In our series of cases liver parenchymal and fibrotic lesions were dominant (Figure 1).

We have also compared the main features of SOS lesions and other associated alterations in samples distal and proximal to the treated tumour. Although there is a lesser degree of hemorrhagic and necrotic lesions in samples taken from non-tumour bearing liver parenchyma (at minimum distance of $20 \mathrm{~mm}$ from the tumour) compared to those from peritumoural zone, we observed evidently narrower (although variable) zone of necrotic and vascular lesions with slightly dilated sinusoidal bed (figure 2). There were visible differences for
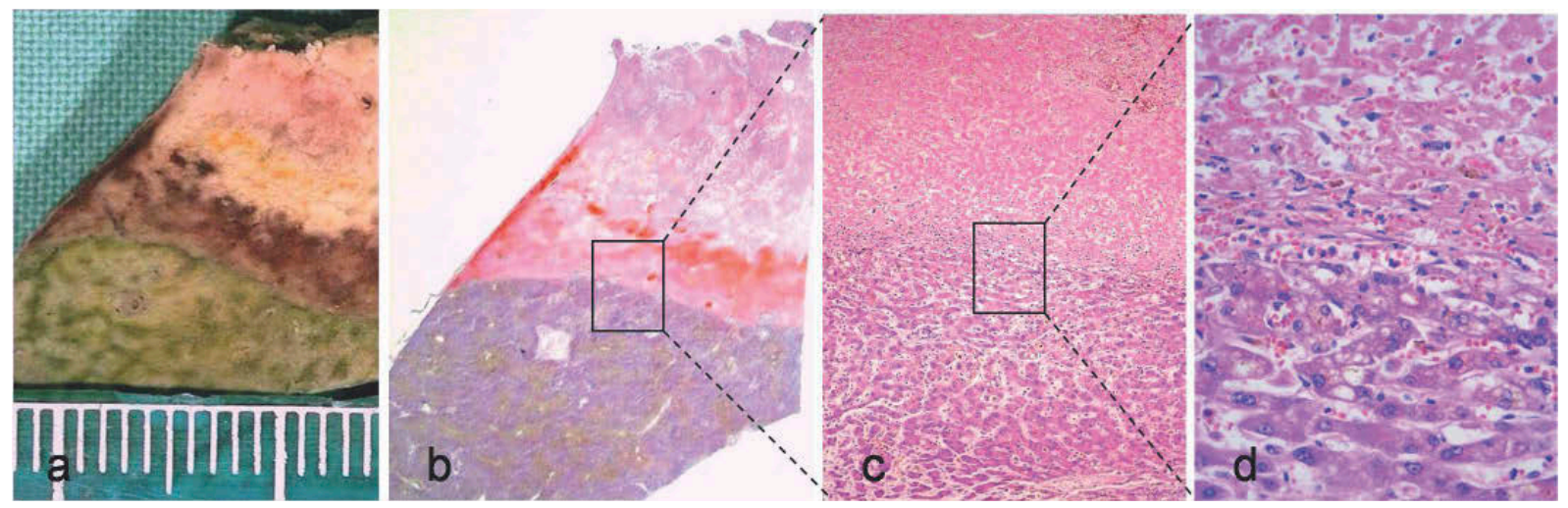

Figure 2. Macroscopic aspect of SOS shows liver congestion with irregular nodularity of hepatic parenchyma and congestive discoloration below necrohemorrhagic zone of treated metastatic colorectal carcinoma (a); the same area presented by whole mount section with boundary zone between necrotic tumour and liver parenchyma in the rectancle (b); closer view depicts RALR-related sharp delineation of necrotic to viable liver tissue showing sinusoidal dilatation and irregular trabeculae of hepatocytes with the same intensity in peritumoural and peripheral zones (c); the loss of endothelial cells and hepatocyte degeneration is less pronounced and restricted to narrow peritumoural zone in cases treated with RALR (d) 
histologic lesions in peritumoural zones between both RALR and non-RALR groups but were not significant: hemorrhagic centrilobular necrosis $(23.2 \%$ vs $39.9 \%, \mathrm{p}=0.81)$, surgical necrosis or surgical hepatitis ( $31.2 \%$ vs $44,7 \%, \mathrm{p}=0.76$ ) and sinusoidal dilataton and congestion ( $45.7 \%$ vs $76.8 \%, \mathrm{p}=0.64$ ).

\section{DISCUSSION}

Histopathology of SOS and associted histopathologic alterations significantly broadens the role of pathologist in evalutation the surgical and oncological treatment for colorectal liver metastases. In addition to verification of histological type and grade as well as residual status by cheking the margins of the resection, the up-to-date patholological report includes further information on other major determinants in management and outcome: the regression grade, i.e. the degree of histological response of the CRLM to preoperative chemotherapy and possible histological alterations in non-tumour bearing liver parenchyma with special attention to the distinctive toxic hepatic lesions associated with chemotherapy (15).

The rationale of neoadjuvant preoperative use of oxaliplatin-based chemotherapy in selected patients with colorectal liver metastases relates to downsizing the tumors that may increase the rate of curative resections, to conversion of unresectable metastases to those that may become eligible for hepatic resection, to identification of good responders among patients and via the regression grade (the degree of response to chemotherapy) to evaluate biologic aggressiveness of tumors as those who progress under chemotherapy may not benefit from resection. However, oxaliplatin-based treatment is accompanied by serious side effects. Several studies has established the prevalence of complex vascular lesions of SOS in oxaliplatin-related liver damage in patients treated for colorectal liver metastases. There are also detailed pathological descriptions and grading of these changes, because its occurrence was associated with high mortality rates. According to current data, one can expect sinusoidal lesions to be found in aproximately two thirds of patients receiving oxaliplatin-based chemotherapy (ranging 38-74\%) dependent on the heterogeneity of applied regimens and type of administration as well as on the level of clinical and histopathological recognition of SOS. Our result with prevalence of $69.35 \%$ of SOS lesions with more than a half with low-grade lesions is consistent with most of european studies $(4,14)$. SOS is in these settings almost always variably associated with various patterns of fibrosis, steatosis and/or steatohepatitis and to lesser degree regenerative nodular hyperplasia. Although the severity and the outcome of SOS is hardly predictable, potentially strong hepatotoxicity can be observed in patients receiving intrahepatic arterial administration of high doses of oxaliplatin and little is known whether these lesions are eventually reversible. Less hepatotoxicity is reported for irinotecan and 5-fluorouracil-based chemotherapy (25-40\%) but coadministration of bevacizumab has been shown to reduce the incidence and severity of sinusoidal changes (4).
On the other hand, pathological lesions of non-neoplastic liver treated by surgery alone showed the prevalence of steatosis present in 37\% (but other types of lesions were not found) and that was not significantly different from that of cases treated by neoadjuvant chemotherapy (39.8\%) (13). Furthermore, development of CASH, i.e. severe steatohepatitis can occur in patients who have received certain types of chemotherapy for colorectal liver metastases such as preoperative administration of oxaliplatin and/or irinotecan, especially in the obese. CASH can limit the ability to perform an extensive hepatectomy and can contribute to postoperative patient morbidity and mortality (11). However, all further studies revealed that most of questions about the interpretation of the histologic lesions has led to the conclusion that SOS develops in the context of steatohepatitis rather than aggravate steatohepatitis itself. This issue is important in order pathogenesis to be better understood and prevention strategies developed (16).

Liver resection type can influence the severity of SOS. In the context of standard liver surgerical procedures for colorectal liver metastases, oxaliplatin-related SOS could increase the risk of intraoperative bleeding and postoperative liver insufficiency. In patients undergoing a major resection combined with radiofrequency procedures, oxaliplatin-associated liver injury was not associated with an increased risk of perioperative (90-day) morbidity or mortality. In contrast, CASH steatohepatitis was associated with irinotecan and with an increased perioperative risk of death, especially (17). This is also consistent with our results showing "high-grade" SOS lesions specially hemorrhagic centrilobular necrosis and peliosis in nontumour bearing liver parenchyma less frequent in patients underwent RALR. It was shown that most severe vascular lesions from the spectrum of SOS that are found in standard liver metastasectomies are associated with increased intraoperative transfusions due to significant blood loss and perfusion-reperfusion effects in the liver sinusoidal bed (14). Bloodless liver resection type such as RALR may represent at least partial explanation for lower rates of surgical hepatitis (surgical necrosis) as well as known better clinical outcome in these patients. Therefore, the extent of liver resection and type and duration of applied chemotherapy regimen should be carefully considered and individualized, including a consideration for body mass index and related comorbid factors.

Etiopathogenesis of SOS is still not well elucidated but has similar and quite consistent histomorphologic features regardless of its cause. In general, it is hypothesized as multifactorial activation of the hepatic sinusoidal endothelial cells and the subsequent toxic destruction of endothelial cells with sloughing and eventually downstream occlusion of terminal hepatic venules (18). Contributing factors include glutathione and nitric oxide depletion of sinusoidal endothelial cells, increased intrahepatic expression of matrix metalloproteinases and vascular endothelial growth factor, and activation of coagulation cascade. However, these mechanisms are described predominantly 
in SOS observed after hematopoietic stem cell transplantation or pyrrolizidine alkaloid exposure. It is still not known whether SOS observed in oxaliplatin based chemotherapy are identical to them, or are mostly related to pro-inflammatory mechanisms. Unlike the previous two, endothelial destruction and hepatocyte necrosis are inconspicuous in oxaliplatin-related SOS both in clinical and in experimental studies and an activation of VEGF and IL6 pathway mediators can result only in sinusoidal dilatation and hepatocyte atrophy $(19,20)$. There is also evidence that an activation of pro-inflammatory pathways can be induced in the tumor itself by chemotherapeutic agents (21).

The role of biopsy with respect to raising the awareness of possible development of SOS is unclear. Some authors have recommended preoperative liver biopsy to evaluate for SOS, steatosis and/or steatohepatitis. However, given the problems associated with unknown or unclear clinical context, sampling error as well as intra-and interobserver variation in the evaluation of histologic alterations, we do not stand for this approach. Rather, laparoscopy before laparotomy is advocated in patients with preoperative imaging suggested steatosis to directly evaluate the liver. Systematic review by Wang et al. disclosed that nearly half of patients with SOS underwent liver biopsy to diagnose the syndrome (210 patients with SOS caused by herbal medicine Tusanqi) in addition to the currently well-established diagnostic criteria for SOS include original or modified Seattle criteria and Baltimore criteria with four major components: bilirubin, hepatomegaly, ascites and weight gain (22). There is no data on diagnostic accuracy of hepatic biopsies as the diagnosis is currently based on sinusoidal lesions, independently of hepatic venous lesions. It depends on the size and type of biopsy samples because sinusoidal and endothelial lesions are discrete: dilated and empty sinusoids could be easily overlooked as well as subintimal edema and fibrin deposits in sinusoids and/or terminal hepatic venules. Peliosis and nodular regenerative hyperplasia could hardly be recognized on routine hematoxylin-eosin staining of needle biopsies but more clearly seen in reticulin preparations and until detailed clinical data and clinical suspicion are presented in the request. Fine needle biopsies are almost useless in diffuse vascular lesions. Acute hepatic congestion should be considered if perivenular sinusoids are dilated and associated with necrosis, little inflammation and brown-ceroid pigment laden Kupffer cells. Chronic venous congestion with fibrotic veins is difficult to demonstrate within the fibrous tissue without some of trichrome or collagen stainings. Rubia-Brandt stated that in pathologic studies, occlusion of the centrilobular veins occurs in 50$75 \%$ of patients who develop SOS after hematopoietic stem cell transplantation, but only in approximately $50 \%$ of patient with SOS after oxaliplatin-based chemotherapy (2).

An accurate and noninvasive tool to predict SOS lesions in the subset of patients receiving oxaliplatin preoperatively is missing, although some risk factors of SOS have been identified. The increase of spleen volume could be helpful in the early diagnosis and pathogenesis of SOS. In a recent animal study of vascular endothelium toxicity caused by herbal medicine Tusanqi, various platelet disorders and other hematologic effects were observed to be associated with splenomegaly (22). It seems more likely that splenomegaly is caused by the change in endothelin in the intersection of liver-spleen axis, but not necessarily linked to chronic portal hypertension (23). Imai et al. also found that the splenomegaly should be an independent predictor of the development of SOS in patients with colorectal metastases who received oxaliplatin-based chemotherapy with or without bevacizumab (24). Previously, Soubrane et al. reported a low preoperative platelet count and high aspartate aminotransferase to platelet ratio index (APRI) might represent the most reliable indicators to predict SOS severity (25). Among determinants for the development of SOS after chemotherapy genetic polymorphism in drug metabolizing enzymes, such as glutathione S-transferase may be important (19).

This study had several limitations. First, all patients with 6 or more cycles regimen of preoperatively chemotherapeutic treatment with fluorouracil plus oxaliplatin were included. However, variable duration of neoadjuvant chemotherapy and dose-dependent oxaliplatin-related effects could be relevant for the severity of SOS and other histological abnormalities. Second, there was no groupings of patients who underwent major and minor liver resection, although no statistical difference was found between the patients with regard to the frequency of blood transfusion (12). Third, only a short-term (6-24 months) surgical follow-up result could be provided in this study, mostly with relatively good outcome. Most of death events and other major complications occurred during a relatively short follow-up period. The most common cause of death might be acute liver failure, rather than portal hypertension-related complications. However, the long-term follow-up was lacking.

\section{CONCLUSION}

Our results confirmed recent reports that sinusoidal obstruction syndrome is a major feature of hepatic lesions associated with oxaliplatin neoadjuvant chemotherapy for liver colorectal metastases. Although the impact od oxaliplatin-related SOS on clinical outcome is unclear and in many cases minimal, it can be associated with increased postoperative morbidity after major liver resections and with a decreased tumor response. We found severe vascular abnormalities in non-tumour bearing liver parenchyma such as hemorrhagic centrilobular necrosis and peliosis to be less frequent in patients underwent RALR for colorectal liver metastases and they might be associated with better clinical outcome in these patients.

These preliminary findings might be important for clinicians as well as pathologists to recognize SOS with respect to possible complications and the impact on overall therapeutic results. Further studies should be necessary to explore the long-term follow-up results and refine diagnostic possibilities and the treatment strategy. 


\section{REFERENCES}

1. DeLeve LD, Valla DC, Garcia-Tsao G. Vascular disorders of the liver. Hepatology. 2009; 49:1729-1764.

2. Rubbia-Brandt L. Sinusoidal Obstruction Syndrome. Clin Liver Dis. 2010; 14:651-668.

3. DeLeve LD, Shulman HM, McDonald GB. Toxic injury to hepatic sinusoids: sinusoidal obstruction syndrome (veno-occlusive disease). Semin Liver Dis 2002; 22:27-42.

4. Valla D-C, Cazals-Hatem D. Sinusoidal obstruction syndrome. Clin Res Hepatol Gastroenterol. 2016; 40:378-385.

5. Lin G, Wang JY, Li N, Li M, Gao H, Ji Y, Zhang F, et al. Hepatic sinusoidal obstruction syndrome associated with consumption of Gynura segetum. J Hepatol. 2011; 54:666-67.

6. Adam R. Colorectal cancer with synchronous liver metastases. Br J Surg. 2007; 94:129-131.

7. Nordlinger B, Sorbye H, Glimelius B, Poston GJ, Schlag PM, Rougier P, et al. Perioperative chemotherapy with FOLFOX4 and surgery versus surgery alone for resectable liver metastases from colorectal cancer (EORTC Intergroup Trial 40983): a randomized controlled trial. Lancet. 2008;371:1007-1016.

8. Adam R, Delvart V, Pascal G, Valeanu A, Castaing D, Azoulay D, et al. Rescue surgery for unresectable colorectal liver metastases downstaged by chemotherapy: a model to predict longterm survival. Ann Surg. 2004; 240:644-657.

9. Fernandez FG, Drebin JA, Linehan DC, Dehdashti F, Siegel BA, Strasberg SM. Five-year survival after resection of hepatic metastases from colorectal cancer in patients screened by positron emission tomography with F-18 fluorodeoxyglucose (FDG-PET) Ann Surg. 2004; 240:438-447.

10. Rubbia Brandt L, Audard V, Sartoretti P, Roth AD, Brezault C, Le Charpentier M, et al. Severe hepatic sinusoidal obstruction associated with oxaliplatin-based chemotherapy in patients with metastatic colorectal cancer. Ann Oncol. 2004;15:460-466.

11. Fernandez FG, Ritter JJ, Goodwin W, Linehan DC, Hawkins WG, Strasberg SM. Effect of Steatohepatitis Associated with Irinotecan or Oxaliplatin Pretreatment on Resectability of Hepatic Colorectal Metastases. J Am Coll Surg 2005; 200: 845-853.

12. Milićević M, Bulajić P, Žuvela M, Dervenis C, Basarić D, Galun D. A Radiofrequency-Assisted Minimal Blood Loss Liver Parenchyma Dissection Technique. Dig Surg 2007; 24:306-313.

13. Rubbia-Brandt L, Lauwers G Y, Wang H, Majno P E, Tanabe K, Zhu A X, et al. Sinusoidal obstruction syndrome and nodular regenerative hyperplasia are frequent oxaliplatin-associated liver lesions and partially prevented by bevacizumab in patients with hepatic colorectal metastasis. Histopathology 2010; 56:430-439.
14. Aloia T, Sebagh M, Plasse M, Karam V, Lévi F, Giacchetti S, Azoulay D, Bismuth H, Castaing D, Adam R. Liver histology and surgical outcomes after preoperative chemotherapy with fluorouracil plus oxaliplatin in colorectal cancer liver metastases. J Clin Oncol. 2006; 24:4983-90.

15. Vreuls CP, Van Den Broek MA, Winstanley A, Koek GH, Wisse E, Dejong CH, Olde Damink SW, Bosman FT, Driessen A. Hepatic sinusoidal obstruction syndrome (SOS) reduces the effect of oxaliplatin in colorectal liver metastases. Histopathology. 2012; 61:314-8.

16. Rubbia-Brandt L, Mentha G, Terris B. Sinusoidal obstruction syndrome is a major feature of hepatic lesions associated with oxaliplatin neoadjuvant chemotherapy for liver colorectal metastases. J Am Coll Surg. 2006; 202:199-200.

17. Vauthey JN, Pawlik TM, Ribero D, Wu TT, Zorzi D, Hoff PM, et al. Chemotherapy regimen predicts steatohepatitis and an increase in 90-day mortality after surgery for hepatic colorectal metastases. J Clin Oncol. 2006; 24:2065-2072.

18. Mohty M, Malard F, Abecassis M, Aerts E, Alaskar AS, Aljurf M, et al. Sinusoidal obstruction syndrome/ veno-occlusive disease: current situation and perspectives-a position statement from the European Society for Blood and Marrow Transplantation (EBMT). Bone Marrow Transplant. 2015; 50:781-9.

19. Rubbia-Brandt L, Tauzin S, Brezault C, Delucinge-Vivier C, Descombes P, Dousset B, et al. Gene expression profiling provides insights into pathways of oxaliplatinrelated sinusoidal obstruction syndrome in humans. Mol Cancer Ther 2011; 10:687-96.

20. Agostini J, Benoist S, Seman M, Julie C, Imbeaud S,Letourneur F, et al. Identification of molecular pathways involved in oxaliplatin-associated sinusoidal dilatation. J Hepatol 2012; 56:869-76.

21. $\overline{\text { Marzano C }}$, Cazals-Hatem D, Rautou PE, Valla DC. The significance of nonobstructive sinusoidal dilatation of the liver: impaired portal perfusion or inflammatory reaction syndrome. Hepatology 2015; 62.3: 956-963.

22. Wang X, Qi X, Guo X. Tusanqi-related sinusoidal obstruction syndrome in china. A systematic review of the literatures. Medicine. 2015; 94:e942.

23. Tarantino G, Scalera A, Finelli C. Liver-spleen axis: intersection between immunity, infections and metabolism. World J Gastroenterol. 2013; 19:3534-3542.

24. Imai K, Emi Y, Iyama KI, et al. Splenic volume may be a useful indicator of the protective effect of bevacizumab against oxaliplatin induced hepatic sinusoidal obstruction syndrome. Eur J Surg Oncol. 2014; 40:559-566.

25. Soubrane O, Brouquet A, Zalinski S, Terris B, Brézault C, Mallet V, Goldwasser F, Scatton O. Predicting high grade lesions of sinusoidal obstruction syndrome related to oxaliplatin-based chemotherapy for colorectal liver metastases: correlation with post-hepatectomy outcome. Ann Surg. 2010; 251:454-60. 